\title{
Between clarity and disorientation: remarks on the unease of Wolfgang Streeck with the 21st century migration
}

\author{
Ludger Pries (Ludger.Pries@rub.de) \\ Ruhr-Universität Bochum, Germany
}

In his essay, Wolfgang Streeck as "a sociologist-cum-political economist" and "a non-specialist in a field of social and moral action as highly complex and emotionally charged as migration" expresses his unease with certain aspects of the scientific and political debates on migration, especially in the context of the so-called migration crisis of 2015 . He expresses special discomfort with not being able to situate the corresponding discourses and arguments in a classic left-right-spectrum. For the author, during the recent refugee movement in Europe a romanticising and moralising, charity driven and cosmopolitan Left mobilised support and resources for refugees, who illegally entered EU member states and better (and cheaper) would have been looked after in the regions of their origin. He himself argues in a moral way when stating: "committing for allegedly moral reasons scarce resources to a goal that cannot be achieved is not just futile but may be morally wrong as it forgoes more effective alternatives" (4).

This basic line of arguments is developed in a strange mix of stories, accounts and colportage in three steps. In the first section Streeck deals with "immigration regimes as contested institutions" and mixes aspects of labor migration and refugee protection. He tries to analyse - and criticise - the attitudes and statements of what he calls "the pro-immigration Left" (6). Supposedly looking from the standpoint of a highly experienced rational intellectual with no particular interests, experiences and preferences, the text criticizes a supposed liberal-libertarian Left aiming "to open domestic labor markets for everybody from everywhere" (ibid.). The author detects that "Christian ideas of supposedly universal charity and boundless beneficence are called upon to discredit legal distinctions between citizens and non-citizens as well as between categories of immigrants with different legal entitlements" (7). According to this statement, the state is reduced to maintaining a secular order and opposed to the principle of charity.

This is in contrast to the century-old understanding of the social or welfare state and to distinguishing the principles of insurance and neediness (Versicherungs- versus Bedürftigkeitsprinzip) as both crucial for understanding state activities and responsibilities. The author tends to draw a line between a liberal-deregulatory and charity-driven Left, on one side, and the supporters of the modern, rights-based welfare state, on the other side (9). Nevertheless, things are more complicated, as there are some Leftists in policy (like in the party "Die Linke") and in science (like Deutschmann, 2016), who argued against immigration in general and against opening the borders for refugees in 2015 reasoning that this would endanger the rights of the lower stratus of the working class. Also, since Thomas Marshall the state could not simply be reduced to guaranteeing civil rights, but has to be considered as committed also to economic and social rights, and actually also to global and international rights (like refugee protection and Human Rights). 
Although headlined "immigration regimes", there is no reference to the complex multilevel governance structure in the field of economic as well as of refugee migration. The Geneva Convention for refugee protection defines basic civil rights for anybody. These rights are signed by almost all nation states, but also integral part of the Aquis Communautaire of the European Union. The German constitution has a special paragraph 16 granting asylum to politically persecuted persons. Besides this refuge-oriented asylum regime with its "Common European Asylum System" there is the principle of free mobility inside the Schengen space which includes almost all EU member states plus some others (Pries, 2018, 85). Discussing migration policy and immigration regimes without even mentioning some of these details could only lead to passionate oversimplification and populist prejudices - even when trying to present oneself as a superior and confident intellectual. The second paragraph deals with the challenges of managing diversity in receiving countries. The basic argument refers to migration in general - again making no distinction between the different governance structures for labor and for refugee migration - and to the supposedly "economic costs of a large-scale intake and resettlement of immigrants (...) and the limits of social integration in a culturally diverse society" (9). There is actually no empirical evidence that for nation states or national societies - because this is the underlying unit of analysis in Streeck's reasoning - in general costs of immigration are higher than their benefits (Bonin, 2014). International scientific debate concentrates, conversely, on the costs of emigration, especially of well-trained persons, for the countries of origin. In general terms, in the case of labor migrants as well as refugees, better off emigrants are able to organize and finance mobility up to the richer countries of the North. Poor migrants remain in the neighbouring countries that lack economic development or concentrate organized violence. An extensive study of more than a million refugees who arrived in the USA between 1987 and 2016 found higher employment rates, equal income and higher skilled jobs than the average population (Kerwin, 2018). The economic and demographic benefits of immigration for Germany are well documented (Bonin, 2014). Critical assessments of brain drain effects fall short. For instance, at mid of the 2010s, some 600 physicians were trained in Bulgaria and left university - the same amount left the country. The same general tendency holds for integration and managing migration-related diversity. As stated constantly e.g. by the German Expert Council of Scientific Foundations for Migration and Integration (SVR), integration in Germany in general works well. Especially where people have contact to each other, socio-cultural diversity is seen more as enrichment than as a danger. Spatial segregation by ethnic, language or religious groups is higher in many immigration countries like the USA, Great Britain or France than in Germany (Musterd, 1998; Petermann \& Schönwälder, 2015, 505). Socio-ethno-cultural grouping or clustering is not challenging by nature, but it depends on the overall societal environment and institutional setting.

In light of empirical evidence and scientific debates of those familiar with the topic, basic arguments presented by Streeck in this second section are mainly those found normally in discourses of right-wing politicians and alleged intellectuals. The author scoffs: "Welcoming les miserable offers an opportunity (...) to demonstrate unconditional compassion: a soft heart" (11). He relates migration and refuge to the "no-go-areas" where "enclaves often police themselves" (11) and terrorist groups may recruit their people. This might be the case in some spatial areas, but in general criminal rates are not significantly higher with migrants (Walburg, 2016). Since the founders of sociology, like Emile Durkheim and Georg Simmel, we know that social cohesion as 'organic solidarity' derives not from gathering the ever same socio-ethno-cultural groups, but from the degree of social differentiation and 'crossover of social circles'. Streeck uses the term parallel societies (Parallelgesellschaften) that "are likely to form" (12) as a by-product of immigration and could lead to increased internal surveillance. The term parallel societies is mainly used by right-wing people like 
Thilo Sarrazin and does not address really existing milieus like those of the right-wing extremist "citizens of the Empire" (Reichsbürger), who actually aim at creating parallel state structures (refusing to pay taxes and to obey to public laws, but inventing their passport etc.).

The last section has a promising heading: "migrants as strategic actors". Nevertheless, what is discussed in science since almost a decade and especially in light of the refugee movement of 2015 as a crucial empirical fact (Pries, 2018; Feischmid et al., 2019), is used by Streeck as a warning "that many migrants are far from having no alternatives - and equally far from being indifferent as to where they receive protection" (16). The subtext of this section could be read as: migrants - again there is no differentiation made between labor migrants and refugees - move in social networks, they have their own agenda, "about sixty to eighty percent of applicants in Germany claim to have on their way lost their passports" (16), for many persons migration is a "business venture (17), they send money back home, being interrogated by officers they tell stories spread by smugglers (18), and they are suspected of "a capacity and inclination for <opportunism with guile>" (18). Streeck uses the term "migrants as strategic actors" not for contrasting to a dominant perspective on migrants as passive victims, but for insinuating that they are cheating and defrauding actors just picking in an opportunistic way the most beneficial entry category and country of origin (15f.).

The author mentions a number of actually worrying events like in New Year 2015/16 in Cologne, where some migrants and refugees capitalized on the relaxed atmosphere for sexual harassment. But this is not the main topic when discussing scientifically the issue of migrants as collective actors. According to scientific evidence, people leave their home and family based on collective decisions and on having almost no economic (labor migrants) or security alternatives (refugees). They have and share some general goals. Nevertheless, migration processes then are sequential and iterative, influenced by contingencies and luck (Pries, 2018, 188f.). Nowadays, and especially since the refugee movement of 2015, refugees use social networks for day-to-day decisions on how to proceed. Most migration movements are mixed migration flows as there is no clear boundary between voluntary and involuntary migration (Pries, 2018, 19f.). As long as no solutions come to the places of conflict and misery, where people are living, they will migrate and look for solutions where they expect them. Streeck relates "refugees' strategic capacity" (19) to the moral hazard of exploiting wealthier countries' willingness to help. But the main moral hazard is for the refugees themselves. And the argument that the more rescue ships are cruising in the Mediterranean Sea, the more refugees will feel invited to come to Europe might have some truth, but the conclusion to stop rescue at sea in order to stop refugee movements misses the point of a solution to the legal, social and moral problem.

In sum, as the author confesses from the beginning, he is not a specialist in the topic. In his essay he gathers a huge amount of wordy arguments against the practice of refugee protection. But he fails to actually treat the structural problems that exist. Unfortunately, the used literature is very poor, mainly based on articles of one German (conservative) newspaper. The vague use of terms and concepts additionally weakens the text which at the end has to be read as a defeatist arm chair reasoning and not as a stimulating provocation. The crucial problems and challenges are not addressed: In times of globalization and multi-level transnational entanglements of social spaces, the world still is divided and structured by nation-states as gatekeepers for inclusion and exclusion, for rights and privileges. Although effective and strong democratic nation-states are crucial for guaranteeing rights, welfare and security, they are, as Daniel Bell (1987) mentioned, too small for the big problems of life, and too big for the small problems of life. An example for this is the failure of the European Union to cope with the global challenge of refugee protection at a supranational level. As demonstrated by Streeck's paper, methodological nationalism, as 
the habit to treat the nation-state as the almost natural unit of analysis, is still very strong in social sciences and could lead to nostalgic feelings of former times in which the distinction of left and right based on (national) social classes supposedly was still much easier.

\section{References}

Bell, D. (1987). The world and the United States in 2013. Daedalus. Journal of the American Academy of Arts and Sciences 16 (3), 1-31.

Bonin, H. (2014). Der Beitrag von Ausländern und künftiger Zuwanderung zum deutschen Staatshaushalt. Gütersloh: Bertelsmann-Stiftung. Download: https://www.bertelsmannstiftung.de/fileadmin/files/user_upload/Bonin_Beitrag_Zuwanderung_zum_dt_Staatshaushalt_141204_nm.pdf (retrieved 11.01.2019).

Deutschmann, C. (2016). Einfallstor für Rechts. Mitbestimmung, Nr. 1/2016, 21-23. Download: http://www.boeckler.de/pdf/p_mb_1_2_2016.pdf (retrieved 11.01.2019).

Feischmidt, M., Pries, L. \& Cantat, C. (Eds.) (2019). Refugee protection and civil society in Europe. Houndmills: Palgrave.

Kerwin, D. (2018). The US refugee resettlement program - a return to first principles: How refugees help to define, strengthen, and revitalize the United States. Journal on Migration and Human Security 6 (3), 205-225. https://doi.org/10.1177/2331502418787787 (retrieved 11.01.2019).

Musterd, S., Ostendorf, W. \& Breebaart, M. (1998). Multi-ethnic metropolis: Patterns and policies. Dordrecht: Springer Science+Business Media.

Petermann, S. \& Schönwälder, K. (2014). Immigration and social interaction. European Societies 16 (4), 500-521.

DOI: $10.1080 / 14616696.2013 .865064$.

Pries, L. (2018). Refugees, civil society and the state. European experiences and global challenges. Cheltenham: Edward Elgar.

Walburg, C. (2016). Migration und Kriminalität - aktuelle kriminalstatistische Befunde. Berlin: Mediendienst-Integration. Download: https://mediendienst-integration.de/fileadmin/Dateien/Gutachten_Walburg_Kriminalitaet_Migration.pdf (retrieved 11.01.2019). 